\title{
Langdon Winner's Theory of Technological Politics: Rethinking Science and Technology for Future Society
}

\author{
ERNST SCHRAUBE \\ ROSKILDE UNIVERSITY \\ DENMARK
}

\begin{abstract}
In the 2020 Prague Virtual Conference of the Society for Social Studies of Science (4S), Langdon Winner was awarded the society's John D. Bernal Prize jointly with Sharon Traweek. The Bernal Prize is awarded annually to individuals who have made distinguished contributions to the field of STS. Prize recipients include founders of the field of STS, along with outstanding scholars who have devoted their careers to the understanding of the social dimensions of science and technology. This response to Winner's Bernal lecture reflects on his theory of technological politics, its implications for the psychology of technology as well as its relevance for rethinking science and technology for future society.
\end{abstract}

\section{Keywords}

technology and politics; psychology of technology; democratic shaping of technological change

\section{Introduction}

Today, we live in a historically unprecedented epistemic-political situation. Planet Earth, including the human life it sustains, is in serious trouble. People around the globe are concerned and social movements like Fridays for Future or Extinction Rebellion gain traction. Within the sciences including STS, scholars increasingly realize the danger and put it into the center of their thought. As a response, a critical selfreflection has turned to the question of how modern science has been part of the problem as well as how we have to fundamentally rethink our conception of science, technology and the production of knowledge. Langdon Winner's body of work brings us to the center of this concern. He locates the danger in a fatal discrepancy in the relationship between humans and technology. The structure of human creation represents an arc of action encompassing both the creation of the artifact and the artifact's recreation of the human being. However, in the modern world, the second part of the process becomes increasingly out of control: autonomous technology. Winner's vision of a Theory of Technological Politics engages in this dilemma. It asks not just what people do with technology, but also what technology is doing with us and our world. It engages to reconnect the maker with the making, to turn toward the things themselves and to examine critically the nature and significance of technological artifacts in human and more-than-human life on planet Earth.

Copyright (C) 2021 (Ernst Schraube). Licensed under the Creative Commons Attribution-NonCommercialNoDerivatives 4.0 International (CC BY-NC-ND 4.0). Available at estsjournal.org.

To cite this article: Schraube, Ernst. 2021. "Langdon Winner's Theory of Technological Politics: Rethinking Science and Technology for Future Society." Engaging Science, Technology, \& Society 7.1: 113-117. https://doi.org/10.17351/ests2021.811. 
I met Langdon Winner for the first time in August 1998. He picked me up at Albany airport when I was coming for a one-year research visit to the STS department at the Rensselaer Polytechnic Institute (RPI). It was the beginning of a close friendship and collaboration. I had just finished my $\mathrm{PhD}$ on the psychology of technology at the Free University in Berlin. The University's psychology department was one of the best in Germany during that time, a space for systematically rethinking psychology as a science. Its vision was to unfold a societally relevant psychology, which turns toward the problems of human life in the contemporary world, and to form a frame for investigating the internal relationship between human subjectivity and the everyday world. The world of technology, however, was not an issue.

In my PhD I examined why it was so difficult for psychology to engage with the technological and material dimension of human life. Drawing on the work of the philosopher of technology Günther Anders, I argued for an epistemic shift from a disembodied, isolating and individualizing scientific vision toward an embodied psychology of technology situating psychological processes both in the subjective and the sociotechnological dimensions of the practice of everyday living. Although Anders' writings offer an extensive critical deliberation of the significance of technology in human life, I was missing a more systematic vocabulary of how to theorize technology. STS and in particular Langdon's body of work offered exactly the framework of a critical theory of technology I was looking for.

That year at RPI was one of the best in my academic life. To study the political implications of technological change together with a broad range of interdisciplinary scholars and to reinvent qualitative inquiry to investigate the intimate relationship between people and technology was just exciting. Already in the car, Langdon mentioned that Lewis Mumford lived quite close to RPI. A few weeks later, we drove together to the little village Amenia, New York to see Mumford's house and garden and discussed in detail his theory of authoritarian and democratic technology. We realized that the house was just for sale. Why not transform it into a retreat for critical scholars of technology, a Center for Technology and Human Prospect? Langdon immediately wrote a letter to find funding (an extended version was published soon after; Winner 2000).

Within Langdon's perspective, psychology constitutes an integrated part of a theory of technological politics. Technological creations and their implications involve human subjectivity, experience and agency. In contrast, for psychology as a science it is quite a challenge to understand the relevance of a theory of technological politics. In recent years however, more and more psychologists realize the importance of material objects and their meaning in human life, and we can find deep engagements with science and technology in their deliberations (Chimirri and Schraube 2019). Psychological concepts, such as Sherry Turkle's notion of technological artifacts as evocative objects (1984), or James Gibson's theory of objects as affordances (1986), or my suggestion of technology as materialized action (2009), propose taking material objects in themselves seriously and elucidate the limits of an instrumental notion of technology. Technological creations are more than just means to an end, neutral instruments that humans can do something with individually or collectively. These artifacts also do something with humans and our world. As soon as we realize that technologies do something and embody action, the question concerning politics arises. 
Politics refers to a particular form of human action. If we humans would exist as single individuals in the world, political action would be superfluous. However, we exist in the plurality, we are social beings living our everyday lives together with others in the world. Political action refers to how intersubjective relations and the formation and ordering of the societal world are established. As Hannah Arendt notes: "Politics arises in what lies between men and is established as relationships" $(\underline{2005}, 95)$, and she emphasizes: "For at the center of politics lies concern for the world... Wherever people come together, the world thrusts itself between them, and it is in this in-between space that all human affairs are conducted" (ibid., 106). Politics is a worlding practice in which power and authority are always at play. Not only because of the question of who, why, how (with which intentions and interests) and on the basis of which principles (such as freedom, social justice, care for a possible future) participates in forming and establishing the social world, but also because of the reciprocations of the created conditions in human affairs.

Langdon's theory of technological politics substantiates a fundamental change in perspective of how to understand politics: politics does not just involve human action, but also the realm of technology. Not only in the sense that modern politics are technologically mediated and build on a material infrastructure, but that technology in itself is a political phenomenon. Technology embodies politics. Not only human action, but also the materialized action of things is political. "Technology is politically significant in its own right," Langdon explains $(2020 a, 21)$, "the machines, structures, and systems of modern material culture ... embody specific forms of power and authority" (ibid., 19).

The theory of technological politics involves three major dimensions. (1) Technological artifacts embody a political function, because particular political ideas, needs and interests are projected in the process of creation and inscribed intentionally into the devices. Because things are doing something, because of the projected reciprocations, they are being done. A much-discussed example would be the particular politics inscribed in the construction of low-hanging bridges in some areas of New York City (ibid., 22ff). (2) Technological artifacts embody a political function, because their doings are more than what was intended. The reciprocations exceed the projection. Artifacts represent a site of magnification and embody a surplus of meaning which can bring human imagination to its limits. Both, the intentional and unintentional doings of things are political. The unintentional doings are even more politically significant, because they unfold a power whose meaning for human life has not been adequately imagined, intensifying thereby the discrepancy between humans and technology. (3) Therefore, the theory of technological politics engages in democratic practices of shaping technological change. Similar to legislative acts, technological innovation requires spaces for public debate and democratic deliberation (such as citizens' panels or agencies for technology assessment) including engagements in creating and designing alternative forms of technological practice. Forms that are systematically, from the first moment in the process of creation, imagined in their significance for human life and the world, and which do not solidify one-sided interests, social injustice and control over others, but try to overcome it and embody a generalized thinking, care for the world and for the common good.

During the past few decades, the theory has been taken up by people around the world. Usually, not as a fixed set of sterile concepts, ready to be applied, but more as a starting point, an epistemic-political framework to 
think with and to expand within specific fields of research, education and politics. In my own work, the conversations with Langdon are always present. Currently, for example, we are discussing the significance of digital technologies in educational practice, including the tension between the visions of a Screen New Deal versus a Green New Deal during the Coronavirus (COVID-19) pandemic (Schraube 2020; Winner 2020b). Another example would be how Langdon helped us at Roskilde University to establish a new educational program. 20th century higher education was formed by a strict division between the social/human sciences and the natural/technical sciences which contributed to the discrepancy in the relationship between humans and technology. The formation of STS was a response to this divide. Building on and extending STS programs' sensibilities, we established HumTek as a new, radical transdisciplinary bachelor program about Humans, Technology and Design. Weaving together more than thirteen disciplines, it centers on an integrated understanding of the human-technology relationship including participatory approaches to the design of technical devices, processes and systems. From the first day of their studies, students reflect on the internal relation between technological design and world-making and discuss why in design processes "it always pays to ask in advance about the qualities of the artifacts, institutions, and human experiences currently on the drawing board" (Winner 2020a, 18).

Our historical situation requires an epistemic shift from knowing more and more about less and less towards an inquiry and understanding of the phenomena in their worldly connections. As Donna Haraway emphasizes, a tentacular thinking $(2016,30 \mathrm{ff})$ is required and a careful analysis of human creation as an arc of action which includes both the projections and the reciprocations. The necessity for such an analysis has still not been properly recognized and too much emphasis is placed on a technological fix. Of course, the development of new technologies is vital. However, there is still a radical imbalance between technological development and an understanding of its significance for human and more-than-human life on planet Earth. Langdon's body of work matters more than ever before. It offers elemental bricks for rethinking science and technology for future society.

\section{Author Biography}

Ernst Schraube is Professor of Social Psychology of Technology at the Department of People and Technology, Roskilde University, Denmark. More info: www.ruc.dk/ schraube.

\section{References}

Arendt, Hannah. 2005. The Promise of Politics. New York: Schocken Books.

Chimirri, Niklas A., and Ernst Schraube. 2019. "Rethinking Psychology of Technology for Future Society: Exploring Subjectivity from Within More-Than-Human Everyday Life." In Psychological Studies of Science and Technology, edited by Kieran C. O'Doherty, Lisa M. Osbeck, Ernst Schraube and Jeffery Yen, 49-76. Cham: Palgrave Macmillan. https://doi.org/10.1007/978-3-030-25308-0 3.

Gibson, James J.1986. The Ecological Approach to Visual Perception. New York: Psychology Press.

Haraway, Donna J. 2016. Staying with the Trouble: Making Kin in the Chthulucene. Durham and London: Duke University Press.

Schraube, Ernst. 2009. "Technology as Materialized Action and its Ambivalences." Theory \& Psychology 19(2): 296-312. https://doi.org/10.1177/0959354309103543. 
- 2020. "Learning and the Politics of Digitalization: Rethinking the Practices of Knowing in Times of Crisis." The Psychology of Global Crises Conference. May 27, 2020. YouTube video. https://www.youtube.com/watch?v=HrHrIBsThiU.

Turkle, Sherry. 1984. The Second Self: Computers and the Human Spirit. New York: Simon \& Schuster.

Winner, Langdon. 2000. "Hot Property in Leedsville: The Mumford Property up for Sale." NetFuture: Technology and Human Responsibility 109. Accessed August 19, 2021.

https://netfuture.org/2000/Aug0300 109.html\#2.

—. 2020a. The Whale and the Reactor: A Search for Limits in an Age of High Technology. 2nd ed. Chicago: University of Chicago Press.

_. 2020b. "Preparing for the Wrong Emergency: Visions of Generation Changing Events." The Psychology of Global Crises Conference. May 21, 2020. YouTube video.

https://www.youtube.com/watch?v=LjBWOzu6dAU. 